\section{II. 実験結果の考察}

$\mathrm{Si}, \mathrm{Mg}, \mathrm{K}$ 采触媒では $\mathrm{A}, \mathrm{K}$ 系触媒に比べて著しく低温(70〜 $120^{\circ} \mathrm{C}$, No.1 A, 7) で油の生成を行了事が出来た。これは還元後 触媒の前処理を行わない場合であった。前処理では生成物は水の みであって CO は触媒表面に炭素(化学吸着炭素)）として或いは

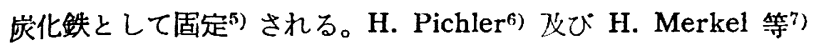
に上れば炭化鉄の形成によって活性は增加すると云われ，一方 H. Kölbel 等象によればこれによって却って活性は低下すると考 えられ，必ずしも結論に達していない。上述の垁験に用いた高活 性触媒では前処理を行わず，従って触媒表面に未だ炭素が多く固 定されずして金属鉄原子よりなる活性中心が存在すると考元られ る時に低温でよく炭化水素を生成した。しかし，短時間の反応の 間飞表面が炭素を固定 ${ }^{9}$ し，又酸化される $\left.{ }^{10}\right)$ ため，その活性を持 晩し難い。この間の生成物は殆んど炭化水素よりなり(No.7 生成 物) 含酸素化合物含量は非常に小であるが，前処理を行って表面 に宸素が固定され炭化鉄が生成らしていると考号られる場合には この含量が增加する事（例えば No. $1 \mathrm{~B}$ ，No. 2 等）を知った。 炭化鉄の生成によって $\mathrm{H}_{2}, \mathrm{CO}$ が活性化吸着寸る模様が変わる事 が知られ(5)，それに伴なって活性，生成物組成の変化が予期され る所であるが，その機構についてはなお多くの実験結果の集積を

4) H. H. Storch, et al. (The Fischer-Tropsch and Related Synthesis p.599 1951)に上れば,この様に呼 ばれる。

5) H. Merkel (H. H. Storch, ibid.p. 479) 飞よ机ば鉄触 媒は $175^{\circ} \mathrm{C}$ より CO によって炭化鉄を形成し始的る。

6) H. Pichler, Brennstoff Chem. 33, 289 (1952).

7) H. Merkel, F. Weinrotter, ibid. 32, 289 (1951).

8) H. Kölbel, F. Engelhardt, Chem. Ing. Techn. 25, 97 (1950).

9）上述実䀦の温度で炭化鉄を生ずるかどらかは未だ明かでな い.

10) H. H. Storch, et al., (The Fischer-Tropsch and Related Synthesis p. 579，1951）によれば炭化鉄は例え ば合成中鉄の酸化を防ぐ様な 2 次的な作用で活性に寄与す ると考えられた。
待たねば結論的なものには達し得ない。この系の触媒を用いた場 合は $\mathrm{A}, \mathrm{K}$ 系中の高活性触媒で比較的低温で反底した時の生成物 に比べてA含量は遥が少ないが，両系の個々について比較を行 そばこの系がこの目的に対して $\mathrm{A}, \mathrm{K}$ 系に劣ると一概に云う事は 出来ない。 $\mathrm{A}, \mathrm{K}$ 系触媒では含酸素化合物を多く得るためには低 反沁温度が必要とされる11)が，この系では低温で却って殆んど炭 化水素よりなる生成物を生じた。又 $\mathrm{A}, \mathrm{K}$ 系触媒の場合廃ガス中 の $\mathrm{CO}_{2}$ 含量は反応温度が低い間は極めて少なかったが，この采 ではNo. $1 \mathrm{~A}, 7$ の場合の様に低温で特に多量の $\mathrm{CO}$ をを生じた。 H. Kölbel'12), R. B. Anderson ${ }^{13)}$, H. (Tramm ${ }^{14)}$ 等によれば鉄 触媒灾用いる場合の炭化水素生成反㤁で生ずる $\mathrm{CO}_{2}$ は， $\mathrm{CO}$ が $\mathrm{H}_{2}$ によって還元されて炭化水素を生ずると同時に生成するすの ではなくてこの反応によって生じた $\mathrm{H}_{2} \mathrm{O}$ が $\mathrm{H}_{2} \mathrm{O}+\mathrm{CO} \rightarrow \mathrm{CO}_{2}+$ $\mathrm{H}_{2}$ に上って $\mathrm{CO}_{2}$ を生ずる2 次的な反応によって副生されると考 えられた。しかし，上述の実験の場合の上うな低温でこの CO 轱 化反応が起ると考穴難いので，この場合 $\mathrm{CO}_{2}$ は岸化水素と同時 に, 例えば $(n+1) \mathrm{H}_{2}+2 n \mathrm{CO} \rightarrow \mathrm{C}_{n} \mathrm{H}_{2 n+2}+n \mathrm{CO}_{2}, n \mathrm{H}_{2}+2 n \mathrm{CO}$ $\left.\rightarrow \mathrm{C}_{n} \mathrm{H}_{2 n}+n \mathrm{CO}_{2}{ }^{15}\right)$ の様にして, 生じたすのと考学られる。

この系の触媒で $\mathrm{NH}_{3}$ 合成活性と, この活性との間には No. 8 で $\mathrm{TiO}_{2}$ の添加が両活性を同様に低下させた外，並行的な関係は 見出されない。この反応では反応生成物が触媒細孔を塞ぐので粒 子内部の触媒表面は活性に寄与し難く, 従って活性は表面積の大 小より寧ろ粒子の大小により著しく影響されると考えられてい る13)。しかし，高活性な No. 7 は $\mathrm{WO}_{3}$ 添加によって得られ,一 方これによって表面積が著しく増加する事を知った。マク口的棈 造測定む又促進剤探索の有效な手段と活性考察への資料を提供す るむのであろう。

（昭和 28 年 4 月, 日化第 6 年会講演)

11) H. H. Storch, et al., ibid. p. 559.

12) H. Kölbel.et al., Chem. Ing. Techn. 23, 153 (1951).

13) R. B. Anderson, B. Seligman, et al., Ind. Eng. Chem. 44, 391 (1952).

14) H. Tramm, Brennstoff Chem. 33, 21 (1952).

15) H. H. Storch, et al., (-The Fischer-Tropsch and Related Synthesis p. 10, 1951)

（横浜国立大学工学部電気化学科：横浜市南区）（昭和 28 年 6 月 24 日受理）

（49）检知管によるカス分析法の研究(第11 報)* 严硫酸カスの迅速定量法

\author{
北 川徹 三・小林 義 隆
}

\section{1. 緒 謇}

硫酸, 硫安, 過燐酸石灰, パルプ等の製造工場, 漂白工業, 又 は金属製鍊等に於ける原料ガス，又は閂ガス巾に含有される亚硫 酸ガス彗度の分析法としては徉来より Raschig 法又は滴定法が 行われていたが，これらよりも更に簡易日つ洮連な分析法が望ま れていた。著者の一人北川は，検知管による再硫酸ガスの迅速測 定法について研究を行い，椧知剤としてシリカダルに吸洋せしめ *) 第 10 報は工化 56, 809 (1953).
た重クロム酸塩を採用した1)。その後この検知管の性能について 詳細な検討を加え，その湘定稌度を高め得たので以下にその概要 を述べる。

\section{2. 実験}

（1）検知管 重ク口ム酸カリの $1 \%$ 水济液 $100 \mathrm{cc}$ を 40〜60 メッシュのシリカゲル粒 $100 \mathrm{~g}$ に吸着させ, $100^{\circ} \mathrm{C}$ 附近の鼬度で 適度に畭燥したもので原色は㣴色で出る。この $0.80 \mathrm{~g}$ を内径約

1) 日本特許 178,082 . 
$3.5 \mathrm{~mm}$, 長さ約 $16 \mathrm{~cm}$ のガラス管に充填し，その充填層の長さ を $L=8 \sim 11 \mathrm{~cm}$ に拈さめた。検知剤の両端は綿栓で固定し，ガ ラス管の両端は熔封して保存性を保たせた。この黃色の検知剤は 覀硫酸ガスに触れると, 鋭敏に反応してク口ム明攀 $\left(\mathrm{KCr}\left(\mathrm{SO}_{4}\right)_{2}\right.$. $\left.\left.12 \mathrm{H}_{2} \mathrm{O}\right)^{2}\right)$ を生じ青色に着色する。

要硫酸ガスを含有する試料ガスの一定体積を一定速度にて梌知 管に送入すれば，検知剤層は入口より逐次青変して，ある長さの 着色層を現わす。この着色層の長さは試料ガス中の西硫酸ガス含 有量に対応しているから㭘知管の着色層の長さを測定することに よって悪硫酸ガス濃度が測定できる。

（2）測定操作法 湘定操作法についてはここでは省略する （第 1 報3）参照)。

（3）西硫酸ガス湌度表及び温度補正表3）検知管に送入する 試料ガスの体積 $V$ 文び送入時間 $T$ は测定する濃度範囲によっ て $V=100 \mathrm{cc}, T=100 \mathrm{sec}$, 欢び $V=50 \mathrm{cc}, T=50 \mathrm{sec}$ の 2 種 とし，夫々の濃度表及び温度補正表を作成した。そして前者によ っては $\mathrm{SO}_{2}$ 0.1 5.0\%, 後者では $0.5 \sim 15.0 \%$ の濃度範囲を測 定することが出来た。ここでは主として前者の場合のみについて 述べる。

（A）㭘知管内径の補正： 充填層の長さ $L$ の異なる検知管 に同一濃度の試料ガス $V=100 \mathrm{cc}$ を $T=100 \mathrm{sec} て ゙$ 送入し, 着 色層の長さ $\boldsymbol{l}$ と $\boldsymbol{L}$ との間の関係を求めた。これより次に示す如 き内径補正式を誘導することが出来た（四省略)。

$$
l_{0}=14 l i(L+3)(\mathrm{cm})
$$

但し $l_{0}$ は充填層の長さ $L=11 \mathrm{~cm}$ を標準とした場合の着色層 の長さを示す.

（B）亜硫酸ガス濃度と検知管の着色層の長さとの関係： 銅 粉と稀硫酸との作用により西硫酸ガスを発生させ, これを約 $20 l$ のガラス瓶中の空気と混合し，滴定法によってその濃度を決定し た。次にこれを清浄な空気で正確にうすめて各種濃度の試料ガス を作り $V=100 \mathrm{cc} ， T=100 \mathrm{sec}$ の条件にて検知管に送入し,亜硫 酸ガス濃度と検知管の着色層の長さとの間の関係を求めた。橫軸 に亜硫酸ガス濃度 $C(\%)$ の対数, 縱軸に着色層の長さ $l_{0}(\mathrm{~cm})$ の対数をとって表わせば第 1 圀の如く直線関係が得られた。故に $20^{\circ} \mathrm{C}$ においては $l_{0}$ と $C$ との間には次の (b) 式が成立する。

$$
l_{0}=2.877 \times C^{0.76}
$$

これらの計算をはぶき測定を簡易化するために第 2 図の如き濃

第 1 検知管の着色圈の長さと亚硫酸カ ス灌度との関保

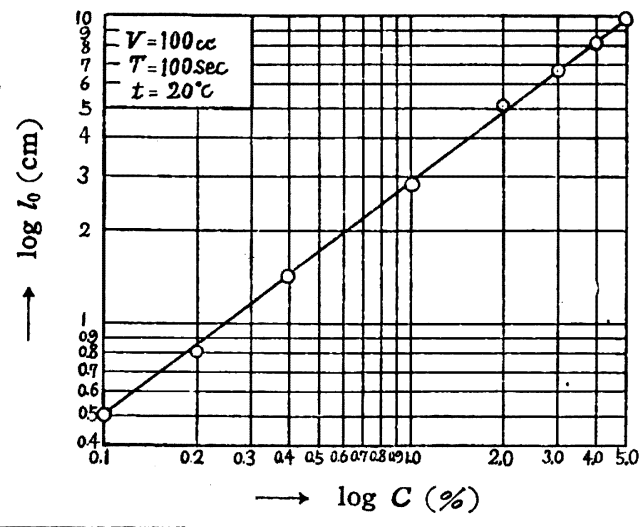

2) 千谷利三, 無機化学 下巻 750 頁.

3）北川, 小林, 工化 55, 191 (1952).

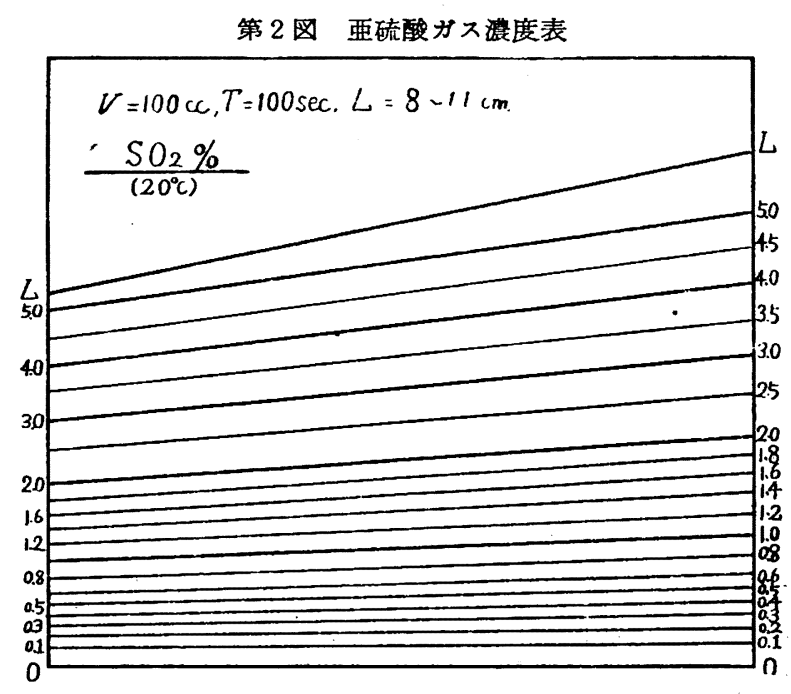

度表を作製した（使用法 省略)。これによって $\mathrm{SO}_{2}$ $0.1 \sim 5.0 \%$ 濃度の測定 が出来る。な抗この場合 の検出限度は約 $0.01 \%$ 即ち $\mathrm{SO}_{2} 30 \gamma$ 附近であ った。

（4）検知管の箱色畨 の曼さに及ぼす各種の影

(A) 送入ガス体積 : この場合に於ては送入ガ ス体積 $V(\mathrm{cc})$ と着色層 の長さ $l_{0}(\mathrm{~cm})$ は直線関
第 3 困 検知管の着色層の長 さと送入ガス体積との関保

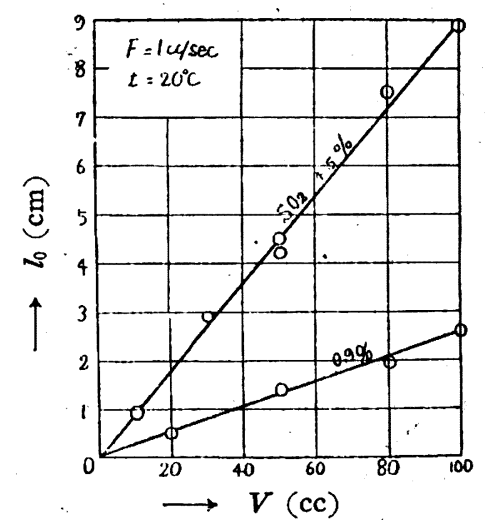
係にあり， $l_{0}$ は $V$ に正比例する（第 3 図参照）。

（B）送入速度：送入速度が大となれば $\mathrm{SO}_{2}$ の一定濃度に 対する着色膡の長さが漸次長くなり，同時にその着色層の境界が 不明膫となる。種々梌討の結果 $F=1 \mathrm{cc} / \mathrm{sec}$ 即ち前述の通り $V=$

\begin{tabular}{|c|c|c|c|c|c|}
\hline \multirow{2}{*}{$\begin{array}{c}\text { 濃度表 } \\
\text { の読 } \\
(\%)\end{array}$} & \multicolumn{5}{|c|}{$\mathrm{SO}_{2}$ 濃 度 (\%) } \\
\hline & $10^{\circ} \mathrm{C}$ & $15^{\circ} \mathrm{C}$ & $20^{\circ} \mathrm{C}$ & $25^{\circ} \mathrm{C}$ & $30^{\circ} \mathrm{C}$ \\
\hline 0.1 & 0.1 & 0.1 & 0.1 & 0.1 & 0.1 \\
\hline 0.2 & 0.2 & 0.2 & 0.2 & 0.2 & 0.2 \\
\hline 0.3 & 0.3 & 0.3 & 0.3 & 0.3 & 0.25 \\
\hline 0.4 & 0.5 & 0.4 & 0.4 & 0.4 & 0.3 \\
\hline 0.5 & 0.6 & 0.5 & 0.5 & 0.5 & 0.4 \\
\hline 0.6 & 0.7 & 0.6 & 0.6 & 0.6 & 0.5 \\
\hline 0.8 & 1.0 & 0.9 & 0.8 & 0.7 & 0.7 \\
\hline 1.0 & 1.2 & 1.1 & 1.0 & 0.9 & 0.8 \\
\hline 1.2 & 1.5 & 1.3 & 1.2 & 1.1 & 1.0 \\
\hline 1.4 & 1.7 & $1.5_{5}$ & 1.4 & 1.3 & 1.2 \\
\hline 1.6 & 2.0 & 1.8 & 1.6 & 1.5 & 1.3 \\
\hline 1.8 & 2.2 & 2.0 & 1.8 & 1.6 & 1.5 \\
\hline 2.0 & 2.5 & 2.2 & 2.0 & 1.8 & 1.7 \\
\hline 2.5 & 3.1 & 2.8 & 2.5 & 2.3 & 2.1 \\
\hline 3.0 & 3.7 & 3.4 & 3.0 & 2.8 & 2.5 \\
\hline 3.5 & 4.4 & 3.9 & 3.5 & 3.2 & 2.9 \\
\hline 4.0 & 5.0 & 4.5 & 4.0 & 3.7 & 3.4 \\
\hline 4.5 & 5.6 & 5.0 & 4.5 & 4.2 & 3.8 \\
\hline 5.0 & 6.2 & 5.6 & 5.0 & 4.6 & 4.2 \\
\hline
\end{tabular}
第 1 表 温度補正表 $\left(20^{\circ} \mathrm{C}\right.$ 基準) 
$100 \mathrm{cc}, T=100 \mathrm{sec}$, 又は $V=50 \mathrm{cc}, T=50 \mathrm{sec}$ で送入する 方式 を採用した。

(C) 測定温度 : 测定時の娭知管の温度 $\left(t^{\circ} \mathrm{C}\right)$ によってもそ の着色層の長さ $l_{0}(\mathrm{~cm})$ が異なることはこれまでの報告と同様で ある。 $l_{0}$ と $t$ との関係は次の (c) 式によって示される。ここで $l_{(t)}, l_{(20)}$ は室温が $t^{\circ} \mathrm{C}$ 及放び $20^{\circ} \mathrm{C}$ に於ける着色尿の長さ $l_{0}$ を表 わす。これより $10 \sim 30^{\circ} \mathrm{C}$ の温度補正表（第 1 表）を作製した。

$$
\begin{aligned}
& l_{(t)}=l_{(20)}(t+50) / 70 \\
& \quad \text { 但し } \quad 30 \geqq t \geqq 10
\end{aligned}
$$

（5）測定精度及び所要時間 滴定法による測定值と㮩知管法 による測定值との此較試験及び並行試験を行い，榆知管法の精度 について実験した。第 4 図は縦軸に滴定法による湘定值，横軸に 検知管法による湘定值をとって表わした。測定值は何れも原点を 通る $45^{\circ}$ の線に近く, 且つその関係㕵差の平均值は $\pm 5 \%$ 以下 であって，実用に供し得る精度であった。なお 1 回の測定に要す る時間は 3 分内外にて充分である。

（6）他のガスの影零 この検知管は酸素 $\left(\mathrm{O}_{2}\right)$, 窒素 $\left(\mathrm{N}_{2}\right)$, 水素 $\left(\mathrm{H}_{2}\right)$, 炭酸ガス $\left(\mathrm{CO}_{2}\right)$, 一酸化炭素 $(\mathrm{CO})$, 水分 $\left(\mathrm{H}_{2} \mathrm{O}\right)$, 無水硫酸 $\left(\mathrm{SO}_{3}\right)$, エチルアルコール $\left(\mathrm{C}_{2} \mathrm{H}_{5} \mathrm{OH}\right)$, アセトアルデ ヒド $\left(\mathrm{CH}_{3}-\mathrm{CHO}\right)$, エーテル $\left(\left(\mathrm{C}_{2} \mathrm{H}_{5}\right)_{2} \mathrm{O}\right)$, ベンゼン $\left(\mathrm{C}_{6} \mathrm{H}_{6}\right)$, ア セトン $\left(\left(\mathrm{CH}_{3}\right)_{2} \mathrm{CO}\right)$ 等の多くのガスによっては全く着色するこ
第 4 因検知管法と滴定法との比較試験

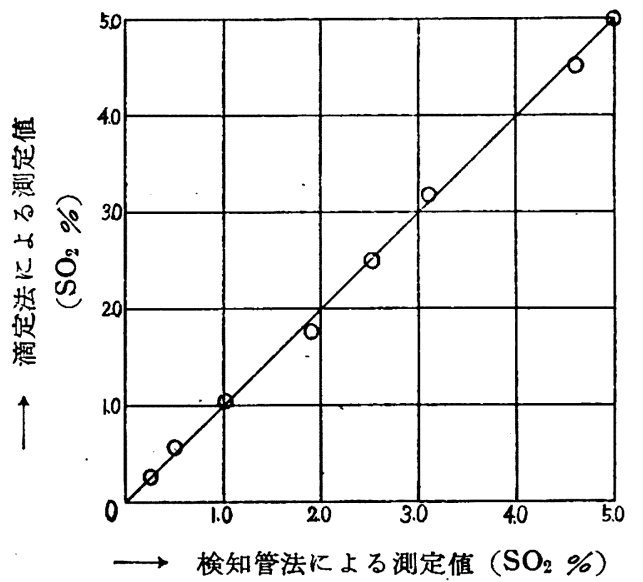

とはないが，濃厚な硫化水素 $\left(\mathrm{H}_{2} \mathrm{~S}\right)$ によって茶に着色する。 亚硫酸ガスと硫化水素の混合ガス中の硫化水素濃度が $0.04 \%$ 以下の場合は影響はない。それ以上の漂度では着色層の長さは延 び, 測定值が高くでるので注意を要する。

本研究は文部省科学研究費により行った。ここに深謝の意を表 する。

（工業技術院東京工業試験所：東京都涩谷区）（昭和 28 年 7 月 15 日受理）

(50) $\mathrm{NH}_{3}-\mathrm{SO}_{3}$ 系無水反応に関する研究 $(\text { 第 } 6 \text { 報 })^{*}$

$\mathrm{NH}_{3}-\mathrm{SO}_{3}$ 間 $の$ 低溫反応

\section{内田章五・伊藤幸夫}

前報までの研究は $100 \sim 200^{\circ} \mathrm{C}$ 附近における $\mathrm{NH}_{3}$ と $\mathrm{SO}_{3}$ の 気相反応を取扱ったものであるが，本報では -33〜ー76C にお ける $\mathrm{NH}_{3}$ と $\mathrm{SO}_{3}$ との気一固相反级敒び液一固相反応についてそ の生成物の組成を予備的に検傠してみた。無水の液体又は固体の $\mathrm{SO}_{3}$ と過剩の液体アンモニアからスルファミン酸アンモニウムを 造る米国特許1)が発表されているが，反応生成物の詳細は発表さ れていないのでわれわれの実験結果を発表する。

\section{実験}

直径 $3 \mathrm{~cm}$ の大型試験管を反応管として用い, ジュワー丵にェ 一テルを澫たし、これに鍼製の蛇管を入れて冷凍機で领却した低 温度のアルコールを循置し，あるいはドライアイスを投入して所 要の低温が得られるよ5にした冷却溶を用い, 次に述べる三つの 方法によって実験を行った。

A. 乾燥した反底管に市販の $\mathrm{SO}_{3}$ を加熱してとかしたものを 入れ, 冷却浴中 ( $\mathrm{SO}_{3}$ は固化する) で $\mathrm{NH}_{3}$ ガスを通じて反応さ せる。

B. 市販の $\mathrm{SO}_{3}$ を加熱してとかし，これを小さな試験管に採 り，ガラス棒を插入し，泠却して固化させた後軽く微温湯につけ

*) 第 5 報は工化 57, 18 (1954).

1) E. J. Tauch, U.S.P. $2,426,420$ (1947).
第 1 解 $\mathrm{NH}_{3}-\mathrm{SO}_{3}$ 間の低温反応装置 (B)

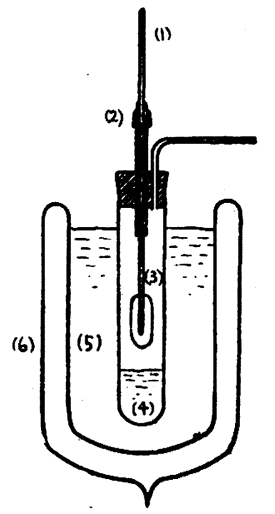

(1) ガラス 棒

(2) 短いゴム管

(3) 固 体 $\mathrm{SO}_{3}$

(4) 液 体 $\mathrm{NH}_{\mathrm{s}}$

(5) 冷 规洛

(6) $シ=ワ-$ 娅

て抜取り，手早く液体アンモニアの入った反応管中に第 1 図のご とく取付け， $\mathrm{SO}_{3}$ のついたガラス棒を上下して液体アンモニアと できるたけ徐々に反応させる。

C. 完全に無水の状態で反応させるため，市販の $\mathrm{SO}_{3}$ を一度 蒸溜して脱水，薄ガラス製の小球に探って熔封し（第 2 図 $\mathbf{I}$ ), これを反忘管内に入れ（第 2 図 II)，硫酸及心゙五酸化燐を通した

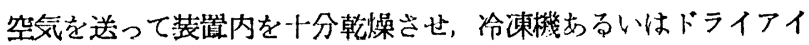

